\title{
Connective Consumptions: Mapping Melbourne's Food Sharing Ecosystem
}

Ferne Edwards and Anna R. Davies

Department of Geography, Trinity College Dublin, Dublin, Ireland

To cite this article: Ferne Edwards \& Anna R. Davies (2018): Connective Consumptions: Mapping Melbourne's Food Sharing Ecosystem, Urban Policy and Research, DOI: 10.1080/08111146.2018.1476231

Published online: 25 Jun 2018.

\begin{abstract}
Food sharing, understood as the collaborative growing, cooking, eating and distributing of food, as well as the sharing of food related skills, spaces and tools, is experiencing a renaissance in cities. From meal sharing apps that are used to exchange home-cooked meals to online maps that reveal surplus harvests, innovative technologies are reshaping food sharing practices. Such initiatives intersect with other food and social movements to form what could be described as "food sharing ecosystems". This paper applies assemblage theory to four food sharing initiatives in Melbourne, Australia, to ascertain the implications of their ecosystems for urban planning and policy.
\end{abstract}




\section{Connective Consumptions: Mapping Melbourne's Food Sharing Ecosystem}

\section{Introduction}

Food sharing, as one of the oldest forms of collaborative behaviour (Jones 2007), is experiencing a renaissance with the emergence of Information and Communication Technologies (ICT) and their capacity to rapidly connect large numbers of people. From meal sharing apps that are used to exchange homecooked meals to online maps that reveal surplus urban harvests, new sociotechnologies are reshaping sharing practices in the twenty-first century (Davies et al. 2017a). Claims are being made that these new ICT-augmented forms of sharing, including food sharing, have potentially transformative sustainability benefits: enhancing social cohesion (Schor 2010), fostering economic vitality (Botsman and Rogers 2010) and improving environmental resource efficiency (Agyeman et al. 2013). Despite concerns about the use of sharing to describe venturecapitalist funded, for-profit enterprises (Davies et al. 2017b), such as web platform Eatwith, optimism remains that emerging ICT-mediated food sharing practices may disrupt mainstream systems towards sustainable pathways, not least with regards to the sharing of space, skills and stuff of food in the city.

To date, research examining urban food experiences, including food sharing, has produced rich but fragmented studies of alternatives to mainstream food systems (Goodman et al. 2012). This knowledge gap has stimulated calls for more holistic attention to urban food using integrative analysis from supranational bodies such as the European Union and the United Nations (Armendáriz et al. 2016). In response, this paper contributes new knowledge to these debates by considering how ICT-mediated food sharing initiatives connect actors, institutions and spaces and the implications of this for urban planning and policy. Drawing on ethnographic research conducted in Melbourne, this paper explores the ways in which food sharing initiatives function and critically considers the efficacy of applying assemblage thinking to better understand food sharing practices policy. First introduced by Deleuze and Guattari in 'A Thousand Plateaus' (1987), assemblage theory offers a poststructuralist perspective on how the social world comes together, providing a bottom-up framework for acknowledging and analysing social complexity. The findings of the empirical research conducted in Melbourne suggests that cities provide a shifting context for diverse 'food sharing ecosystems' consisting of actors, material resources, histories, cultures and networks (both on and off-line) that come together to form provisional assemblages around food sharing initiatives. 
The paper begins by outlining the approaches taken to define food sharing and summarises the food sharing landscape in Melbourne. Four case studies from Melbourne - 3000 Acres, Open Table, the Food Justice Truck and RipeNear.Me - are then analysed through assemblage thinking's constituent features of heterogeneity, relationality, desirability, productivity, deterriorialisation and reterriorialisation (Müller 2015) to reveal patterns within practices of food sharing initiatives. After a brief description and mapping of the component parts of the case studies, the constituent features of assemblage thinking are applied to analyse connections and implications for urban governors, particularly with respect to health, safety, social inclusion and land use policy and planning.

\section{Sharing Food in the City}

Sharing is generally seen to cement social cohesion and build bonds within groups and to establish trading relations (Jones 2007). It is the primacy of acting, experiencing or utilising things with others that emerges as the dominant component of sharing. Food sharing was defined by adding 'food' to the Cambridge English Dictionary's (2017) definition of 'sharing': "Having a portion [of food] with another or others; giving a portion [of food] to others; using, occupying or enjoying food [and food related spaces to include the growing, cooking and/or eating of food] jointly; possessing an interest in food in common; or telling someone about food". This definition was used to delineate 28 search terms to identify ICT-mediated food sharing initiatives through online analysis. The search found more than 4000 initiatives in 100 cities, across 43 countries and six continents. The resulting data was collated and displayed in an online database designed as a map that enables the public to search and link to initiatives, while providing comparative detail of what is shared, and the modalities, organisational forms and technologies used by those initiatives (Davies et al. 2017a; Davies et al. 2017c). Recognising that the online profiles of ICT-mediated food sharing initiatives rarely indicated the scale, scope or process of their activities, nine cities of contrasting contexts (Athens, Barcelona, Berlin, Dublin, London, Melbourne, New York, San Francisco and Singapore) were next selected from the database in which to conduct in-depth, qualitative research. The remainder of this paper focuses on the research conducted in Melbourne.

\section{Melbourne's Food Sharing Landscape}

The online investigation indicated that Melbourne experiences high levels of ICT-mediated food sharing, coming in third place out of 100 cities after London and New York City. It has the highest number of food sharing initiatives from the seven Australian and New Zealand cities mapped with 144 initiatives (Davies et al. 2017d). Melbourne's food sharing landscape exhibits a range of sharing modes (for example; bartering, gifting and collecting such as gleaning and dumpster diving) and different organisational models (for example; for-profit, co-operative and not-for-profit) that 
have emerged shaped by the socio-cultural characteristics of its inhabitants, environmental resource availability, and a range of policies impacting on local food practices. Melbourne is Australia's second largest city and is nestled on the southeastern coast. The sprawling city of 9,985 square kilometres with a population density of approximately 450 per square kilometre consists of 26 municipalities and five shires (Davies et al. 2017d). Melbourne has favourable conditions for urban agriculture located on fertile soils in a temperate zone with an adequate water supply. First pronounced an official settlement in 1837, by 1881 Melbourne was stocked with livestock and poultry, providing for milk, eggs, vegetables and fruits on a household scale (Barrett 1971). Over time the city has experienced ebbs and flows in local food production, as the postwar era introduced the rise of multinational supermarkets, with 'low maintenance' gardens becoming popular in the 1950s, and an influx of immigrants from southern Europe in the 1960s and 1970s bringing with them a returned enthusiasm for vegetable gardening and the keeping of livestock (Edwards 2011). While urban food production declined at times, Gaynor (2006) attests that it never completely disappeared.

The emergence of an environmental movement in the 1970s revitalised domestic food production in Melbourne to generate greater self-reliance and independence for householders (Edwards 2011). Melbourne's dispersed and extensive geographical layout also fostered a landscape of community gardens, urban farms, and community growing programs, including the Collingwood Children's Farm, CERES Community Environment Park, Cultivating Community, the Stephanie Alexander Kitchen Garden Project, and the Asylum Seeker Resource Centre.

Over the last decade, Melbourne's domestic food production has come under pressure from the dominance of supermarkets, drought and other extreme weather events, increasing population, urban densification, peri-urban sprawl, and everyday economic pressures (Buxton et al. 2008; Gaynor 2006). Supermarkets in Australia are some of the most monopolised in the world, with major chains such as Coles and Woolworths owning more than $80 \%$ of the total national market (Burch et al. 2013). Their dominance enables them to control market prices, jeopardising steady income for Australian farmers who are increasingly under stress. Furthermore, a recent report (Carey et al. 2016) identifies that while Melbourne's peri-urban region has the capacity to meet approximately $41 \%$ of the city's current total food needs, an estimated population growth to seven or eight million people by 2050 could see domestic food production fall by up to $18 \%$.

Challenges to food production both within and surrounding Melbourne are exacerbated by issues of hunger, obesity, food deserts and food waste (Foodbank Australia 2016; Huse et al. 2017; Pryor 
2008; Sheridan et al. 2016). Foodbank Australia (2016) reported that one in six Australians experiences hunger annually, with more than a quarter of Australians facing regular food shortages. Over 644,000 people a month access food relief from Foodbank agencies - up by $25 \%$ from Foodbank's 2014 report - placing additional demands on current infrastructures which are severely affected by government-led budget cuts to both environmental and social welfare programs. Huse et al. (2017) estimate that $63.4 \%$ of Australian adults and $27.6 \%$ of children were overweight or obese in 2014/15. At the same time, Melbourne generates more than 900,000 tonnes of edible food waste every year (Sheridan et al. 2016), contributing to abhorrent geographies of hunger and waste. Food sharing has been mooted as a potential fix for some of these ills, claims which are interrogated in the following section.

\section{Interrogating Food Sharing in Melbourne}

This section focuses on ethnographic research conducted in Melbourne from September to December 2016. During this period, 25 semi-structured qualitative interviews and three focus groups were conducted with representatives from local and state governments in the sectors of food health and safety and planning, stakeholders from umbrella food sharing networks, academics and community organisations, and organisers and participants from the four food sharing case studies. Interviews and focus groups took a 'follow-the-food' approach commencing with the organisers in each case study to interview their associated donors, board members, site managers, volunteers and participants. This snowball sampling approach revealed key participants of Melbourne's food movement who often took on multiple roles with a range of organisations. Participant-observation involved attending 42 associated landscape and case study events that included conferences, award nights and festivals in addition to volunteering at food sharing activities, conducting house visits and observing community meetings. Table 1 provides a summary of the fieldwork data collected. All interview data was taped, transcribed, and coded using the software program, NVIVO. Coding noted the types of relations between initiatives, and their respective histories, operations, motivations and activities. Table 2 below charts the case study characteristics. This extensive research methodology captured insights from a wide variety of stakeholders and participants providing a holistic overview of current influences and issues informing urban food sharing, and both tangible and intangible motivations for participation. The following sub-section provides a brief description of the case studies and sketch maps of their inputs, outputs, actors and locations. 
Table 1: Summary of fieldwork data

\begin{tabular}{|c|c|c|c|c|c|}
\hline & Landscape overview & 3000 Acres & Open Table & Food Justice Truck & RipeNear.Me \\
\hline $\begin{array}{l}\text { Unrecorded } \\
\text { meetings \& } \\
\text { conversatio } \\
\text { ns }\end{array}$ & $\begin{array}{l}\text { Council workers \& Councillors from: } \\
\text { - } \quad \text { City of Melbourne (CoM); } \\
\text { - } \quad \text { Bendigo City Council; } \\
\text { - } \quad \text { Moreland City Council; \&, } \\
\text { - } \quad \text { Darebin City Council. } \\
\text { Founder of Neeboz. }\end{array}$ & & & $\begin{array}{l}\text { 2x researcher from } \\
\text { Photovoice \& Deakin } \\
\text { University; } \\
\text { - Monitoring \& Evaluation, } \\
\text { ASRC }\end{array}$ & \\
\hline Interviews & $\begin{array}{l}\text { - } \quad \text { Sustainable Food Officer, Darebin CC; } \\
\text { - } \quad \text { Councillor, Hume CC; } \\
\text { - } \quad \text { 2x reps. Street Trader, State Dept. Health; } \\
\text { - } \quad \text { Food policy researcher; } \\
\text { - } \quad \text { Founder, Sustain; } \\
\text { - } \quad \text { Chef, 'Free to Feed'; } \\
\text { - } \quad \text { Founder, Yume; } \\
\text { - } \quad \text { Co-Founder, Open Food Network; } \\
\text { - } \quad \text {, Commons Transition Coalition \& } \\
\text { - } \quad \text { Co-Foundeable; } \\
\text { - } \quad \text { Founder, The Lemon Tree Project }\end{array}$ & $\begin{array}{l}\text { Project Manager, } 3000 \\
\text { Acres; } \\
\text { - } \quad \text { Founder, } 3000 \text { Acres; } \\
\text { - Garden Manager, } \\
\text { FareShare Garden; } \\
\text { - } \text { Founder, Crossroad } \\
\text { Community Garden } \\
\text { - Operations Manager, } \\
\text { FareShare Kitchen; } \\
\text { Master Estate/ Land } \\
\text { Developer; Manager, } \\
\text { Place } \\
\text { Moreland CC. }\end{array}$ & $\begin{array}{l}\text { - } \text { General Manager, OT; } \\
\text { - } 2 \mathrm{x} \text { Board Members, } \\
\text { OT; } \\
\text { - Rep, Urban } \\
\text { Communities; } \\
\text { - } \text { Donor, Secondbite; } \\
\text { - } \text { Donor, Wild Things; } \\
\text { - Manager, Cultivating } \\
\text { Community. }\end{array}$ & $\begin{array}{l}\text { - Project Manager \& 2x site } \\
\text { managers, FJT; } \\
\text { Director of Humanitarian } \\
\text { Services, ASRC; } \\
\text { - } 2 \mathrm{x} \text { people seeking asylum } \\
\text { attending the FJT. }\end{array}$ & $\begin{array}{l}\text { Participants from: } \\
\text { - } \quad \text { 1x Thornbury; } \\
\text { - } \quad \text { 1x Clifton Hill; } \\
\text { - } \quad \text { 1x Brunswick; } \\
\text { - } \quad \text { 1x Docklands; } \\
\text { - } \quad \text { 2x Box Hill; } \\
\text { - } \quad \text { 1x Mt Albert. }\end{array}$ \\
\hline $\begin{array}{l}\text { Focus } \\
\text { groups }\end{array}$ & & $\begin{array}{l}2 \text { FG with } \mathbf{x} \text { FareShare } \\
\text { Garden volunteers. }\end{array}$ & $\begin{array}{l}1 \text { FG with } 4 \text { organisers, } \\
\text { OT. }\end{array}$ & & \\
\hline $\begin{array}{l}\text { Participant } \\
\text { observation }\end{array}$ & $\begin{array}{l}\text { Attended events: } \\
\text { - } \quad \text { Urban Agriculture Forum } \\
\text { - } \quad \text { Symposium of Australian Gastronomy; } \\
\text { - } \quad \text { Welcome Dinner; } \\
\text { - } \quad \text { RAW event; } \\
\text { - } \quad \text { 2x Peace Meals; } \\
\text { - } \quad \text { Tamil Feast, CERES; } \\
\text { - CoM Food Launch Pad Night. }\end{array}$ & $\begin{array}{l}\text { Attended events: } \\
\text { - } \quad \text { Spring Festival; } \\
\text { - } \quad \text { Fitzroy Garden Build; } \\
\text { - } \quad \text { Site visit with } \\
\text { developers; } \\
\text { - } 3 x \text { Crossroads CG } \\
\text { meetings; } \\
\text { - Crowdfunding Meeting; } \\
\text { - } \quad \text { food prep., FareShare } \\
\text { Kitchen. }\end{array}$ & $\begin{array}{l}\text { Collected produce, cooked } \\
\text { \& participated at: } \\
\text { - } \quad \text { 2x Fawkner Lunch; } \\
\text { - } \quad \text { 3x Fitzroy Lunch; } \\
\text { - } \quad \text { 2x Coburg Lunch; } \\
\text { - } \quad \text { 2x Carlton Lunch; } \\
\text { - } \quad \text { Richmond Pilot lunch; } \\
\text { - } \quad \text { Coburg North Lunch; } \\
\text { - } \quad \text { Brunswick Dinner }\end{array}$ & $\begin{array}{l}\text { Volunteered on FJT at: } \\
\text { - 3x Footscray office; } \\
\text { - 3x Footscray Primary School; } \\
\text { - } \quad \text { 2x Melbourne CBD; } \\
\text { - } \quad 3 x \text { Thomastown; } \\
\text { - 3x Dallas; } \\
\text { Volunteer Induction Night, } \\
\text { ASRC. } \\
\text { Attended 3x community meals, } \\
\text { ASRC. }\end{array}$ & $\begin{array}{l}\text { Auto-ethnography; } \\
\text { House visits \& } \\
\text { exchange: } \\
\text { - } \quad \text { Preston; } \\
\text { - } \quad \text { Clifton Hill; } \\
\text { - } \quad \text { Brunswick; } \\
\text { - } \quad \text { Box Hill; } \\
\text { - } \quad \text { Mount Albert; } \\
\text { - Kew. } \\
\text { Food swap, Kew. }\end{array}$ \\
\hline
\end{tabular}


Table 2. Case study characteristics

\begin{tabular}{|c|c|c|c|c|}
\hline Initiative & $\begin{array}{c}\text { What } \\
\text { is shared }\end{array}$ & $\begin{array}{c}\text { Mode } \\
\text { of sharing } \\
\end{array}$ & $\begin{array}{c}\text { Organisational } \\
\text { Form } \\
\end{array}$ & ICT \\
\hline $\begin{array}{l}\text { 3000 Acres } \\
\text { We want to see more } \\
\text { people, growing more } \\
\text { food, in more places. }\end{array}$ & $\begin{array}{c}\text { Tools } \\
\text { Land } \\
\text { Kowledge and skills } \\
\text { Plants and seeds }\end{array}$ & $\begin{array}{l}\text { Gifting } \\
\text { Selling }\end{array}$ & $\begin{array}{l}\text { Charities and non- } \\
\text { profits }\end{array}$ & $\begin{array}{l}\text { Website } \\
\text { Facebook } \\
\text { Twitter } \\
\text { Instagram } \\
\text { Map } \\
\end{array}$ \\
\hline $\begin{array}{c}\text { Open Table } \\
\text { To reduce food waste and } \\
\text { meet the } \\
\text { neighbours. }\end{array}$ & $\begin{array}{c}\text { Meals } \\
\text { Food } \\
\text { Kowledge and skills } \\
\text { Kitchen spaces and } \\
\text { devices }\end{array}$ & $\begin{array}{c}\text { Gifting } \\
\text { Selling } \\
\text { Collecting }\end{array}$ & $\begin{array}{l}\text { Charities and non- } \\
\text { profits }\end{array}$ & $\begin{array}{c}\text { Website } \\
\text { Facebook } \\
\text { Instagram }\end{array}$ \\
\hline $\begin{array}{c}\text { ASRC } \\
\text { Food Justice Truck } \\
\text { To offer significantly } \\
\text { discounted fresh } \\
\text { produce to people seeking } \\
\text { asylum. } \\
\end{array}$ & $\begin{array}{c}\text { Food } \\
\text { Land } \\
\text { Knowledge and skills }\end{array}$ & Selling & Social enterprise & $\begin{array}{l}\text { ASRC website } \\
\text { Facebook } \\
\text { Twitter } \\
\text { Instagram }\end{array}$ \\
\hline $\begin{array}{c}\text { RipeNear.Me } \\
\text { To increase the quantity } \\
\text { of urban and } \\
\text { sustainably grown foods. }\end{array}$ & $\begin{array}{c}\text { Plants and seeds } \\
\text { Food } \\
\text { Knowledge and skills }\end{array}$ & $\begin{array}{l}\text { Gifting } \\
\text { Collecting } \\
\text { Selling } \\
\text { Bartering }\end{array}$ & For-profit & $\begin{array}{l}\text { Map } \\
\text { Facebook } \\
\text { Twitter } \\
\text { Pinterest }\end{array}$ \\
\hline
\end{tabular}

\section{Acres}

3000 Acres was established in 2013 soon after Scottish landscape architect, Kate Dundas, moved to Melbourne and was unable to find a public plot to grow vegetables. Inspired by 596 Acres, a community organisation in New York that maps vacant public land and connects potential gardeners, she wanted to bring a similar concept to Melbourne. At the same time, the state public health body, VicHealth, had placed a call for funding to ask, 'how can we improve the supply and access of fresh fruits and vegetables in Victoria?' 3000 Acres entered the competition and won. Dundas explains: "the idea was to have this map that people could map spaces around the city and then once they had mapped, they would be able to have a conversation with people who were interested in doing something on that space.” By 2017, 3000 Acres had evolved into an umbrella charity organisation that helps connects community groups access to land to establish community gardens. They also provide a consultancy service to establish community gardens in master planned housing estates and not-for-profit organisations. 3000 Acres' provides services that include: navigating and translating planning legislation for land access; gathering volunteers to join projects; and helping organise working bees to get the gardens up and running once access has been established. 


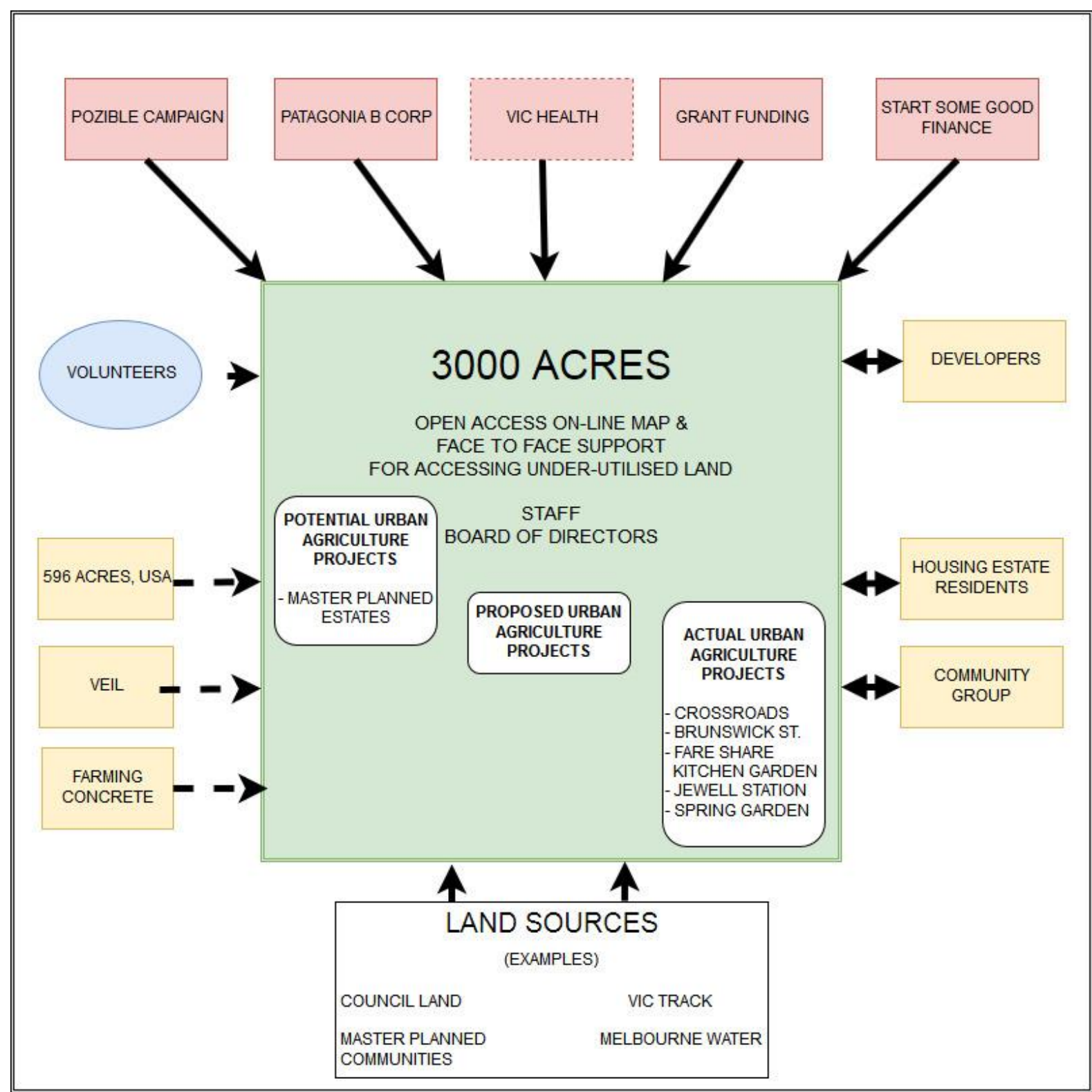

MAP KEY

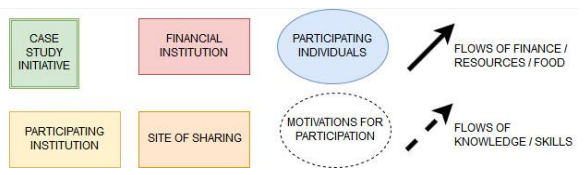

Figure 1.3000 Acres

\section{Open Table}

Open Table is a community organisation that strives to reduce food waste while creating spaces for community interaction. Open Table was started in 2013 by a group of graduate students interested in sustainability who were inspired by a food sharing project in Sweden. They began a six-week pilot program in the Brunswick Neighbourhood House ${ }^{1}$. Open Table's Coordinator explains:

\footnotetext{
${ }^{1}$ Neighbourhood houses, also called Community Learning Centres, are not-for-profit centres that run low cost community programs where people of all abilities, backgrounds and ages can meet others and learn new skills. They are funded by the Victorian Government's Neighbourhood House Coordination Program.
} 
That was one dinner every week on a Sunday evening, and there were maybe six people that were involved in different aspects of getting that together, like promotion, community development, kind of food redistribution. It started out with food coming from FareShare [a Victorian food rescue organisation]. They were donating cooked food ... the project was more about community cohesion at that point, so they were getting in people from some of the lodges in the area, Brunswick Lodge, Stewart Lodge, which is supported housing.

In 2017, Open Table collects surplus food from food rescue organisation, Secondbite, and local businesses to cook free feasts at participating Neighbourhood Houses in the City of Yarra and Moreland. They currently have seven 'feasting' sites - Carlton, Fitzroy, Brunswick, Coburg, North Coburg, Richmond and Fawkner. Open Table events heavily rely on volunteer support. Volunteers often also share the meals they help to prepare with recipients, while the various Neighbourhood Houses sometimes provide paid staff to help with the feasts. Additional sources of funding for Open Table are at times earnt from catering contracts. Serving only one meal per month at each selected venue, Open Table's goal is conviviality rather than food security, with a core focus on overcoming social isolation. 

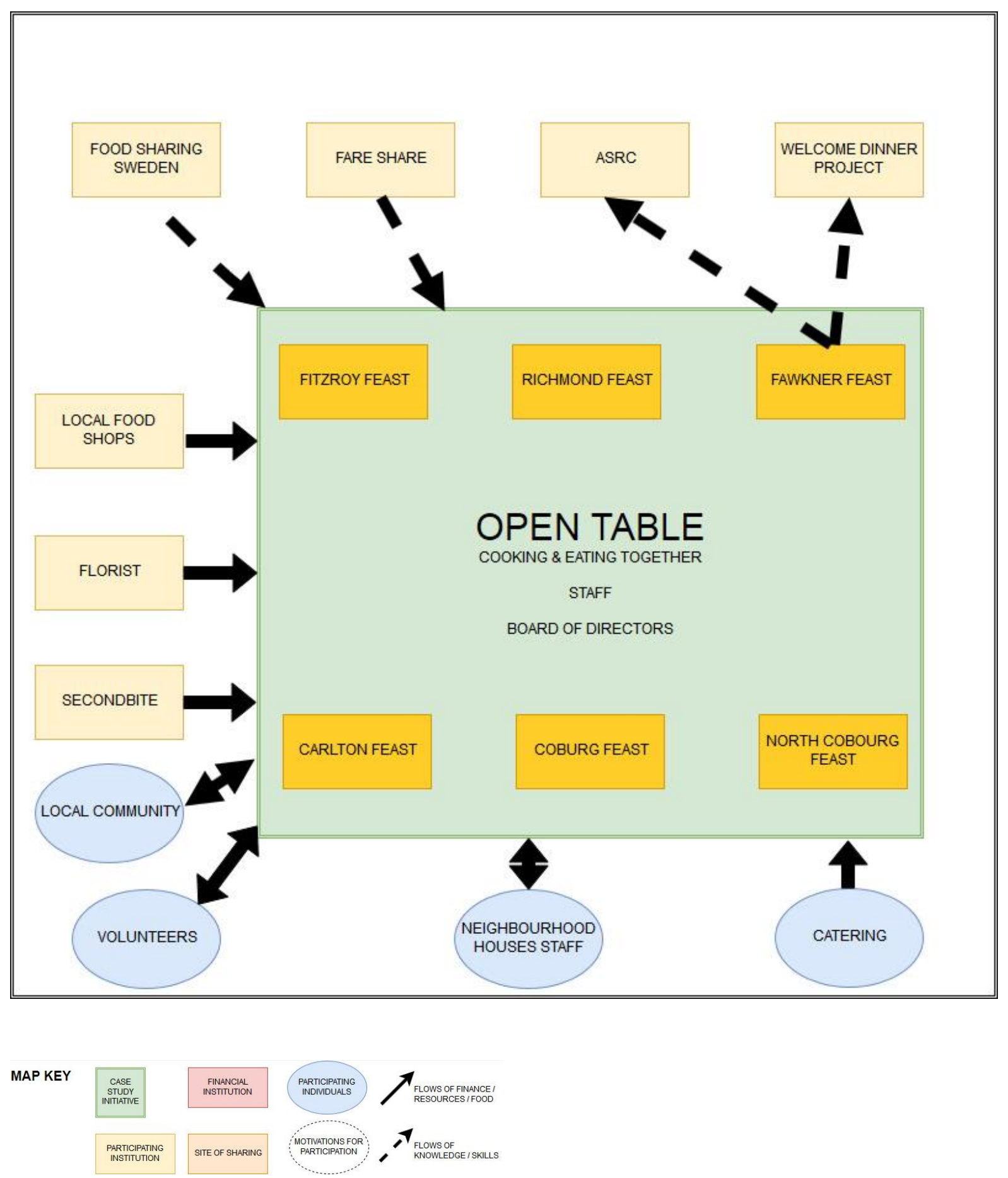

Figure 2. Open Table

\section{The Food Justice Truck}

The Asylum Seeker Resource Centre is an independent, not-for-profit organisation founded in 2001 by Kon Karapanagiotidis, a lawyer and lecturer at Victoria University of Technology. Their goal is to provide programs that empower people seeking asylum "to maximise their own physical, mental and social wellbeing" (ASRC 2016: 2). Karapanagiotidis and his students initially raised funds to create a small foodbank for people seeking asylum, supported by the non-profit enterprise, 
Grasslands Grocery and Information Cafe, who provided the Asylum Seeker Resource Centre with two free rooms above a disused shop in Footscray. Since its establishment, the Asylum Seeker Resource Centre has grown exponentially with two locations, 1200 volunteers and 85 staff who have supported an estimated 3000 people (ASRC 2016). The Asylum Seeker Resource Centre relies heavily on donations but refuses to accept federal government funding due to their immigration policies.

The Food Justice Truck is a mobile fresh food market that was created in 2016 for people seeking asylum. It ceased operating in 2017 when a review proposed reorienting the focus of the Asylum Seeker Resource Centre. The Food Justice Truck was one of three social enterprises run by the Asylum Seeker Resource Centre (the others are a catering and cleaning service), in addition to two food charity programs (a foodbank and a free weekly community lunch). The Asylum Seeker Resource Centre also provided other essential non-food services such as health, case officers and legal advice. The Food Justice Truck shared the Asylum Seeker Resource Centre's philosophy and values, infrastructure and receives advice from the Board of Directors. The Food Justice Truck distributed fresh produce purchased from the Footscray wholesale market to sell at three sites across Melbourne. Sharing was performed through the cost-offsetting of produce by full-paying customers for those seeking asylum. The sharing of space also occured as the Food Justice Truck was designated locations to operate within schools and churches, while the sharing of knowledge about refugee and asylum seeker issues took place as the brightly decorated truck covered with words of thanks to their community of crowdfunders travels around the city. 


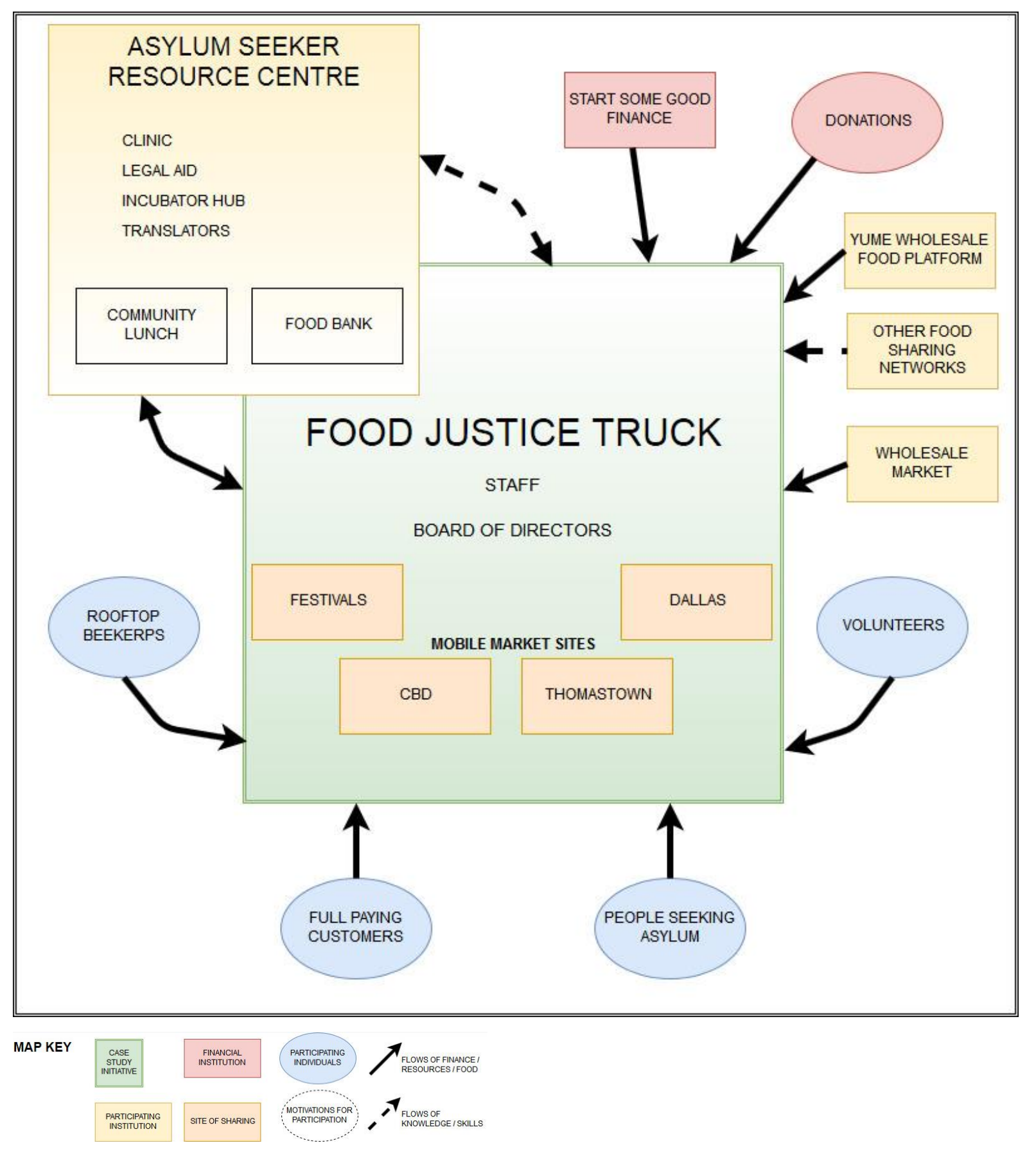

Figure 3. The Food Justice Truck

\section{RipeNear.Me}

RipeNear.Me is a small startup founded by Alistair and Helena Martin from Adelaide in 2012. Their motivation was to connect surplus urban food production with consumers after they had noticed many citrus trees full of fruit going to waste while people continued to buy lemons (some imported) from shops. RipeNear.Me is an online map platform to connect excess food to swap, sell or forage with others. A grower lists their produce, if it is ripe or growing, grown on public or private land, and its price and location. An individual can search for produce by price or growers and they can also subscribe to be notified when produce is ready for collection (Baldassarre 2015). 
The project is mainly self-funded with $\$ 25,000$ raised through StartSomeGood, a crowdfunding platform for social change initiatives, although a partnership was recently established with Australian food manufacter, Continental, a subsidiary of Unilever.
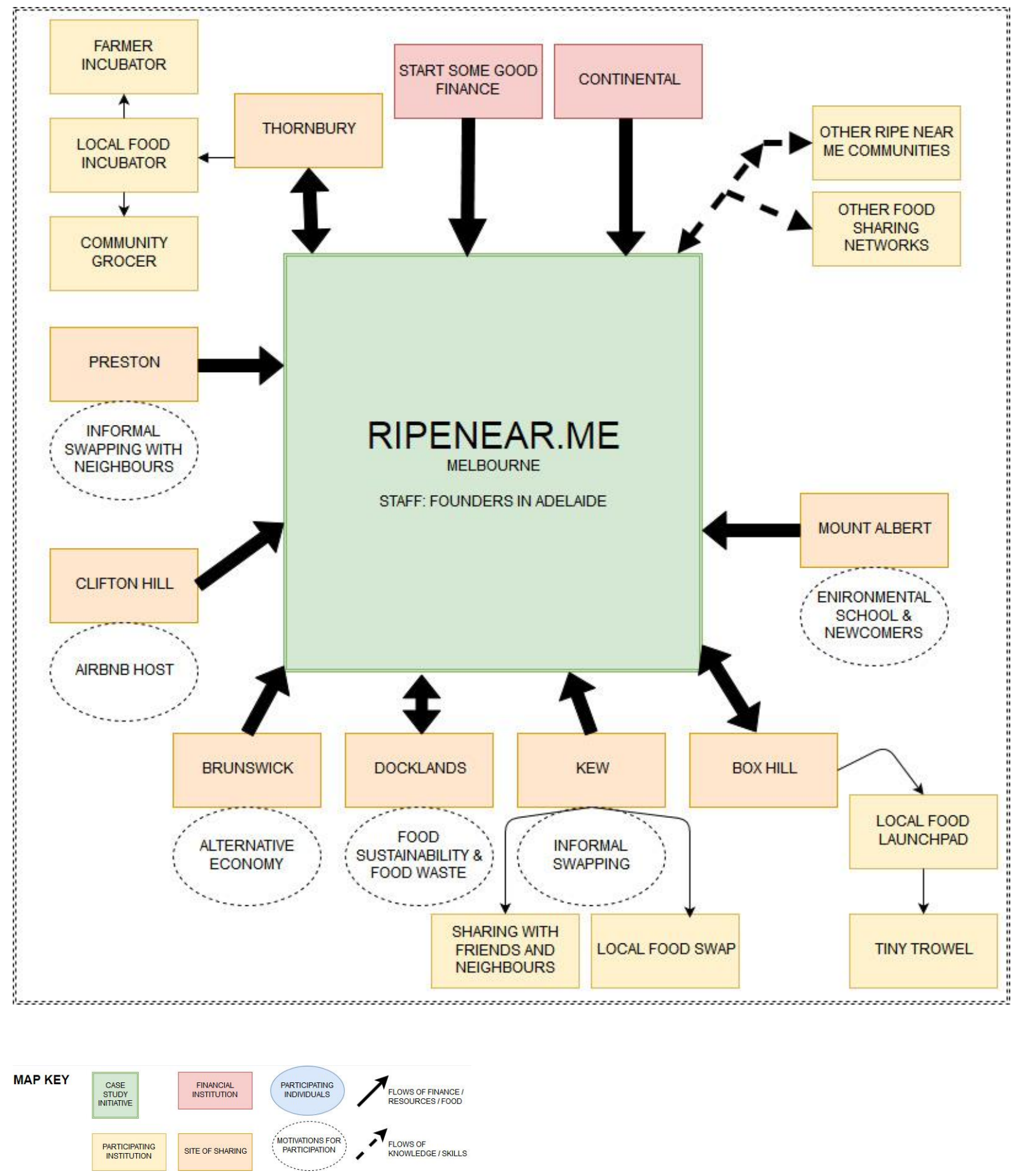

Figure 4. RipeNear.Me

The descriptions and sketch maps of the case studies make visible the relationships and flows that exist within food sharing initiatives. Although not incorporated into the diagrams due to issues of clarity, the changing spatial and temporal, personal and political dynamics within initiatives were 
also noted as significant during the research, and are referred to where relevant in the remainder of the paper. Understanding the ways in which such initiatives emerge and evolve, expand or fade and how they intersect materially and viscerally with others is vital if such initiatives are to be successfully rolled out in new spaces or scaled up beyond locales. The next section applies assemblage thinking to examine the connections and flows of the case studies.

\section{Applying Assemblage Thinking to Food Sharing Practices in Melbourne}

Deleuze and Parnet (1977: 69) define an assemblage as:

a multiplicity which is made up of many heterogeneous terms and which establishes liaisons, relations between them across ages, sexes and reigns - different natures. Thus, the assemblage's only unity is that of co-functioning: it is a symbiosis, a 'sympathy'. It is never filiations which are important but alliances, alloys; these are not successions, lines of descent, but contagions, epidemics, the wind.

Assemblage thinking seeks to understand the complex, shifting and often blurred relationships between actors in forming dynamic events such as establishing a community garden or serving a shared community meal. Assemblage approaches are not simply focused on outcomes but also consider the processes of "gathering, coherence and dispersion" (Anderson and MacFarlane 2011: 124). In his work on dwelling and urban space, McFarlane (2011: 651) redefines 'assemblage' as the verb 'assembling' to denote how cities are always in flux; essentially enacting processes of doing, changing and re-forming. As such, assemblage thinking is often used to describe cyborg urbanisms and urban metabolism (Gandy 2005; Swyngedouw 2006); to think through actor-network theory (Farías and Bender 2009); and to reconsider policy mobilities (Sassen 2007). This paper applies assemblage thinking to the case studies through aspects of heterogeneity, relationality, desirability, productivity, and deterritorialisation and reterritorialisation.

\section{Heterogeneity and Relationality}

Assemblages can take a multiplicity of forms and can include people, place, matter, ideas and discourse with no pre-determined hierarchies or single organising principle. By blurring interactions between humans and non-humans, assemblage thinking seeks to overcome nature-culture binaries (Bennett 2010), as it represents socio-material, socio-ecological and socio-technical 'beings' that are not only heterogeneous but also engage in a multiplicity of relations. For example, analysts have used assemblage thinking to comment on the relational dimension of spatial and socio-political processes. For Malpas (2012: 228), "space appears as a swirl of flows, networks, and trajectories, as 
a chaotic ordering that locates and dislocates, as an effect of social process that is itself spatially dispersed and distributed". Meanwhile, Deleuze cited by Müller (2015: 28) believes that "assemblages consist of relations of exteriority" whose properties "can never explain the relations which constitute a whole". Kennedy (et al. 2013) rephrase relationality to ask how things come "in connection with' each other. Assemblages thus also include the flows that enable components to come together and fall apart, incorporating politics, language, resource constraints, technologies, and personal desires that can galvanize, govern, and destroy what they create.

As illustrated in the previous section, the case studies examined in this paper embrace a heterogeneous range of actors and audiences: 3000 Acres links their stakeholders to community groups; Open Table connects Neighbourhood Houses to their attendees, neighbours and volunteers; the Food Justice Truck addresses needs for people seeking asylum, and RipeNear.Me acts as an open web-based resource for anyone interested in local food. However, while these activities reach a broad audience overall, each initiative's activity tends to remain locally bound within their social community. Every event is also different, as while most activities are held together by a small core team, fluctuating volunteer attendance, resource availability, and the impacts of daily weather, moods and motivations all culminate to produce different scenarios.

The geographic relationality of activities in all the case studies through their location and temporality further impact their outreach. All activities of the food sharing intiatives are multi-sited, prescribing different audiences and outcomes. For example, for 3000 Acres peoples' ability to garden depends upon where land is located and the conditions prescribed by who manages that land, such as the municipality, Melbourne Water, VicTrack, a master planned estate, or private residence. The stability of locations can also impact practices, as 3000 Acres often establishes gardens on temporary land, while Open Table maintains stable yet diverse locations in Melbourne's inner north suburbs. Through its mobility, the Food Justice Truck reaches workers in the CBD ${ }^{2}$ whose spending supports people seeking asylum who often live in the outer suburbs and who are able, as a result, to purchase food at a substantial discount. These place-based and relational geographies at times produce particular outcomes as discovered by the Food Justice Truck who found that people seeking asylum often buy fresh produce in bulk to last the fortnight between deliveries while full-paying customers buy a single luxury item walking by on their lunch break. The need to balance full-paying purchases with discounted goods was one of a number of contributing factors that led to the Asylum Seeker Centre to decide to end the Food Justice Truck to seek out other possible ventures.

\footnotetext{
${ }^{2}$ The Food Justice Truck also attends festivals intermittently where they can sell produce at sale-price.
} 


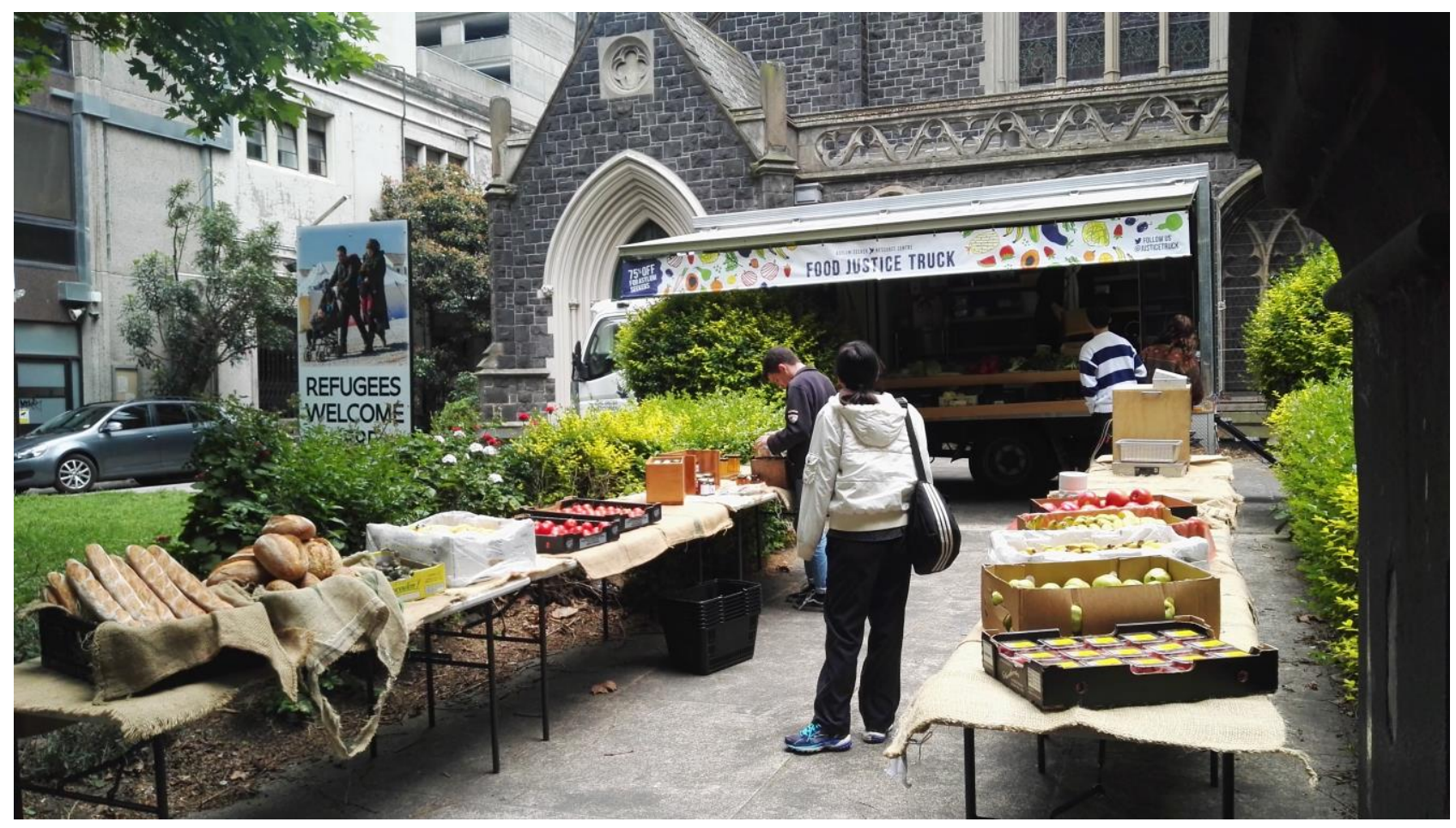

Image 1. Food Justice Truck in the Melbourne CBD

Research showed particular nodes in the assemblages around food sharing create bottlenecks of competition and opportunity. For example, many not-for-profit and community organisations rely on the same charitable foundations or crowdfunding sources, are heavily dependent on volunteers, and often use the same shared spaces to deliver their services. Recognising there are increasingly limited funding opportunities, some food sharing initiatives are experimenting with different organisational models, such as social enterprise and for-profit startup. For example, rather than place more pressure on charity streams, the Asylum Seeker Resource Centre decided to pursue a crowdfunding and social enterprise model. Working with StartSomeGood, the Food Justice Truck received \$153,412 from 933 supporters for the mobile fresh food market. This move from a community not-for-profit to social enterprise is further endorsed through programs such as the Local Food Launchpad.

Alternatively, shared cooking spaces afford opportunities for interaction between like-minded organizations, while they make visible initiatives' motivations and needs across the city. An example of shared space is the Fitzroy Community Food Centre managed by Cultivating Community, a not-for-profit charitable organisation that receives funding from the Lord Mayors Charitable Trust and the Fitzroy Office of Housing. The Food Centre provides a kitchen, dining area, fridges and storage that it shares with several community groups and social enterprises 
including Open Table. Furthermore, this kitchen is located on a block close to the CBD that brings together a rich mix of cultural diversity and socio-economic need, with two public housing complexes, three community gardens (one run by 3000 Acres) and a public space all set in an increasingly gentrified zone.

ICT can also be thought of as providing 'flows of relationality' representing one pathway through which entities connect. RipeNear.Me is the most ICT dependent case study, relying entirely on technology to map and exchange produce online between strangers without the need for a formal governing body. Alternatively, 3000 Acres provides both virtual and face-to-face support with their open source map that is used to identify potential, proposed and current urban agriculture projects. Through their website, participants can post their wish to join a community group and can retrieve land access guidelines for potential partners and land sources for community garden sites. However, while 3000 Acres provides online materials and services, most people continue to contact them directly for support ${ }^{3}$. Both Open Table and the Food Justice Truck engage with ICT in a lesser extent using a website and some social media platforms.

Whilst ICT provides a means to create new pathways of relations, these relations are not necessarily always positively received nor universally accessible. The case studies reveal issues of [mis]trust and social exclusion when applying certain technologies to food sharing initiatives. By using an online format as their base, RipeNear.Me is open to people in the general community who can access such technologies. Participant observation revealed that RipeNear.Me participants frequently feel uncomfortable telling strangers when they will be home to collect cuttings as they fear possible criminal activity, while online formats may be socially exclusive for food sharing initiatives that work with people with potentially less access to and knowledge of complex ICT, such as people seeking asylum, the elderly and the socially disadvantaged. It is for this reason that the Food Justice Truck and Open Table maintain a range of communication methods to connect their diverse participants, such as keeping to monthly schedules, phone calls, leaflet drops, notices at market sites and house visits.

Food sharing initiatives exist due to the diverse flows of skills, social connection, shared places and resources, and the variety of communication methods that move between the various actors. The lenses of heterogeneity and relationality highlight different points of conjunction between actors and components on geographical and temporal scales that draw out issues of social inclusion,

\footnotetext{
${ }^{3}$ At the time of the research, only one group had successfully navigated their way using the online information to access a community land plot.
} 
transference, scales and multifunctionality as a source of survival, resilience and adaptation. The next section discusses how desire and productivity draw such diverse dynamic assemblages together.

\section{Desirability and Productivity}

Desire is what binds heterogeneous parts to form a corporeal whole. Müller and Schurr (2016) in their study of the global market for assisted reproduction align desire with affect: the capacities of bodies to both affect and be affected. For Deleuze and Guattari (1983: 6), affect is not a result of assemblage but allows assemblages to coalesce: "desire constantly couples continuous flows and partial objects that are by nature fragmentary and fragmented". Desire acts as both a positive, productive force and as a destabiliser that takes assemblages apart (Deleuze and Guattari 1986: 59). Desire can be constructed and distributed at many levels, and even has the ability to transgress boundaries of nature and culture (Müller and Schurr 2016).

Food sharing drives and derives desire on two planes: its practice is both felt within the body as affect and emotion, and through the mind in pursuit of individual and group motivations. The act of eating physically incorporates nutrients within the body, generating feelings, taste and energy while sustaining life (see Hayes-Conroy 2013). Viscerality, emotions and affect are central to the embodiment and engagement of food sharing initiatives as participants dig holes, cart dirt, chop vegetables, smell produce for ripeness, swap recipes, eat together and do the washing up. The very

act of food sharing necessitates felt bodily sensations that linger, be it the ache in muscles, in a warm memory of shared experience, or in the afterglow of a healthy meal. 


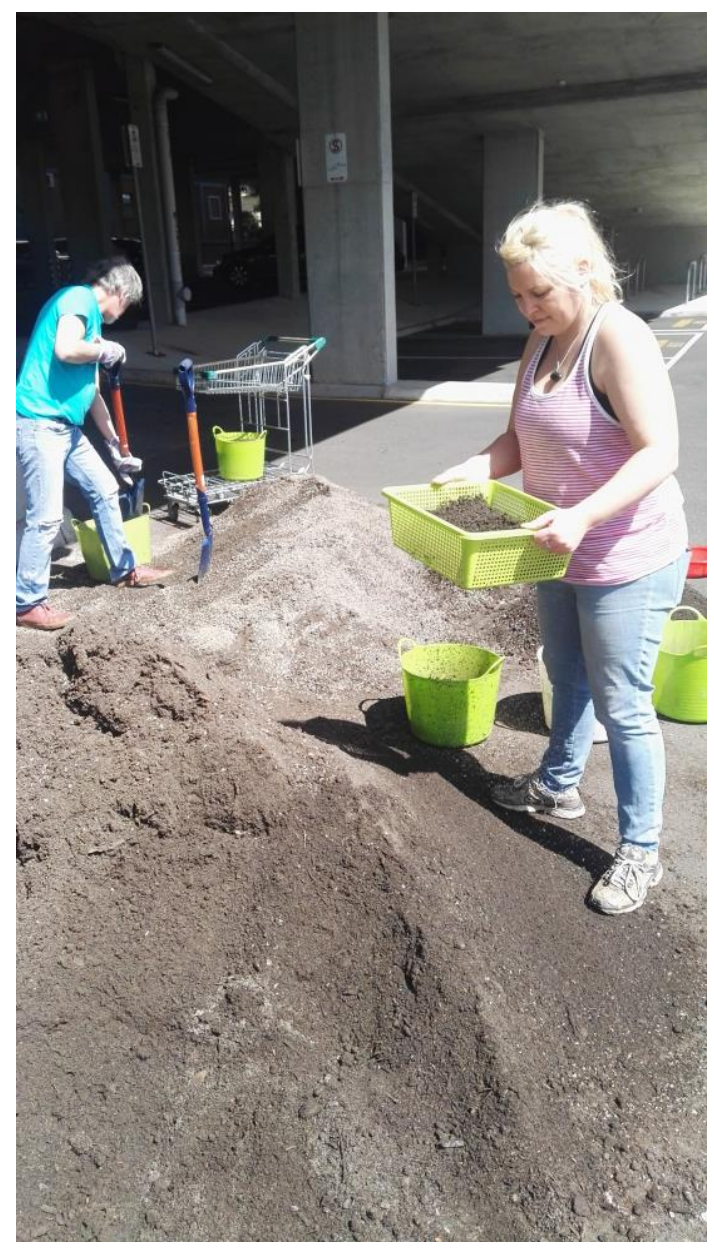

Image 2. Fitzroy Garden Build with 3000 Acres

Collective desire is more commonly understood through the statement of goals. Each case study's website identifies their respective goals as: "to see more people growing more food" (3000 Acres), "to reduce food waste and meet the neighbours" (Open Table), "to offer significantly discounted fresh produce to people seeking asylum" (Food Justice Truck), or "to increase the quantity of urban sustainably grown foods" (RipeNear.Me). Collective goals coalesce with the doing of food sharing, creating unique personal assemblages that either drive them to return or distance them from future participation.

The coupling of desire with action provides an important entry point for access and integration into a social group. During a focus group, organisers of Open Table events admitted that even they find meeting new people quite intimidating. By embracing a simple everyday task such as slicing ingredients for a meal, they can engage and contribute while diverting attention from themselves to create a transitional space in which to acclimatise to the people, space and the conversations around them. This gentle process of integration by doing was witnessed at an Open Table event in Carlton 
where a very shy girl entered the kitchen, quickly secured a potato peeler and silently peeled vegetables for hours. Later she joined everyone else for a meal at the table.

Food sharing initiatives are productive in many ways: in the food they share, swap and sell; in the spaces they inhabit; and in the skills they develop. They also produce an array of emotions, bodily knowledges, social relationships, new identities and understandings. The research revealed that food sharing practices are also generative, producing the basis for unexpected and ongoing food sharing practices to occur. Moments of informal and unexpected sharing also occurred as a form of cultural exchange with people seeking asylum who gifted homemade produce accompanied by a story from home, while RipeNear.Me hosts, excited to have someone interested in their home harvest, would offer more plant clippings than their initial offerings. An unexpected outcome of RipeNear.Me's website was the connection between 'outsiders' with people already wellestablished in food sharing practices. Through the online map, two respondents became involved in offline food activities; one in food swaps and gifting food to her neighbours and colleagues, and another who enrolled in the Local Food Launchpad to later establish her own community food initiative.

Another unexpected outcome occurred at the Fawkner Open Table where a volunteer chef created her own cultural menu of Pakistani food. Her menu became very popular, drawing in regular donated supplies that were essential for the meal but that could not be sourced from food rescue sources. Through a combination of ICT and the quality of the meal (affect!), many Pakistani guests began to attend (often women with children) who shared tables with local residents who are primarily Greek and Italian descent, in turn contributing to better intercultural interaction and understanding. This positive story of sharing represents a personal assemblage of social history, race and knowledge rather than a given or universal experience of food sharing (Hayes-Conroy 2013). The chef, becoming more confident in her cooking through volunteering at Open Table, has since become an Outreach Person for the Asylum Seeker Resource Centre and a host for another cultural food sharing project, the Welcome Dinner Project. Hence, productive performances of sharing tend to propagate further moments of sharing in a virtuous circle of action with some tangible and tasty results.

Desire can also act as a destabiliser that takes assemblages apart (Deleuze and Guattari 1986: 59). A lack of desire or commitment can cause initiatives to stagnate and even collapse, highlighting the need for constant, careful management of relations between an assemblage's heterogenous parts. Melbourne's food sharing initiatives could not exist without the support of their volunteers, while 
the construction of an initial community base is essential for the success of many activities. For example, if there is no community to maintain the garden after its establishment, as in the case of 3000 Acres, it will fail. Or, if organisers at an Open Table event do not welcome the local community to attend, the meal and their combined effort will go waste.

\section{Deterritorialisation and Reterritorialisation}

Deterritorialisation and reterritorialisation refers to the process of de- and re- assembling components with the potential to harness the power necessary for transformational change (Müller 2015). Power may be determined by who governs flows - such as state rules or community desire as assemblages come together and fall apart, as well as where assemblages can take us. Deleuze and Guattari (1987: xvii) differentiate between two types of power: 'puissance' representing immanent power with the potential to affect and be affected, and 'pouvoir' as actualised power. For Melbourne's food sharing initiatives, the desire for change can be identified at various levels to include: the re-valuing of underutilised resources, the imagining of new futures, and the potential and actual power to disrupt urban planning and policy.

All the case studies recognise the first two reterritorialisations: 3000 Acres and RipeNear.Me seek to apply ICT as a tool to revalorise underutilised lands for increased food production, while Open Table provides face-to-face engagements to create spaces for social equity and inclusion through making the shared meal across the city. As a result, Open Table's monthly feasts offer a safe place for people to return and eat a free healthy meal, while through building skills and social connections they are contributing to an immanent and at times an actualised basis for change in small but substantial ways.

Another form of de- and re- territorialisation occurs in the re-use and design of space for urban agriculture. By constructing gardens on public land, 3000 Acres and others are making visible alternatives that can contribute to new normalisations for the use of urban space. McFarlane (2011: 662) speaks of such visualisations as a means to communicate and "disrupt dualisms of 'interior' and 'exterior' through translation". The Carlton Community Learning Centre, the site of an Open Table event, provides an example of visualisation where their community garden can be easily seen through a fence in a high-traffic business zone. Working bees in the garden tend to grab passerbys' attention which can lead to participation, some becoming attendees at the Open Table lunch. As a result, Latour's deployment of 'inscription' works well here to describe how the temporal formation and disassembling of ideas and actions in new spaces - such as productive gardens - can be used to 'lure' interest by testing the possibilities of what could happen (and possibly persist). Latour's 
inscription (1999: 306) refers to "types of transformations through which an entity becomes materialized into a sign, an archive, a document, a piece of paper, a trace”. 'Inscription', 'trace' and 'map' all suggest an exploration of tentative possibilities "where the actualized city that is but one version of what is possible" (Dovey and Ristic 2017). The de- and re- territorialisation of food sharing practices also occur through the re-assembling of policy and planning approaches to create more adaptive and multi-use schemes as discussed in the next section.

\section{Food Sharing Implications for Urban Planning and Policy}

Engagement between planning and policy and food sharing occur mainly at the junctures of food health and safety, and land use. Prince (2017) acknowledges that policies themselves are mobile assemblages, cutting across place and scale to be re-interpreted and enacted by actors on arrival. While overarching themes persist, these may dilute or alter in translation, making it is essential to understand the boundaries, actors and forms of local governance.

Both Open Table and the Food Justice Truck comply with health and safety policies established by the Victorian government body, Streatrader. Streatrader oversees legislation for temporary and mobile premises that include food trucks, shared cooking spaces, and home-based cooking operations. Procedures outline required kitchen and storage fittings, the types of allowable food exchanged, and regular inspections. These rules are enforced by Melbourne's muncipalities ${ }^{4}$ with this localised governance at risk of confusing interpretation. Representatives of Streatrader say that frictions can sometimes arise between state and local government as councils struggle to shift their approach to adapt to changing business models. Streatrader's representatives explain: "Even with shared cooking spaces, some councils are a little bit unreasonable in the requirements [that] they place on these businesses. So again, rather than enabling them, they will sometimes put barriers in place." Hence, Streatrader occupy an emerging regulatory space that stretches between state and local government and traditional and new forms of distributed and temporary services.

RipeNear.Me also exists within an inbetween legal space representing a hybrid of community and commercial services with their website placing responsibility on participants "to employ the same safety measures you would in any other circumstance, as relevant to your community"5, such as interactions with strangers, childcare, and identifying locations. To remain on the side of safety,

\footnotetext{
${ }^{4}$ Exemptions for registration include people who are not making food to sell, businesses who donate food, and community groups that sell food to the public such as for a school fete.

${ }^{5}$ See https://www.ripenear.me/faq\#t3n26.
} 
they do not advocate for the online exchange of meat as they "cannot guarantee the welfare or humane slaughter of animals"'.

RipeNear.Me and 3000 Acres also engage with regulatory issues regarding private and public land use. RipeNear.Me defer the listing of public produce that is not owned by the participant to "contact the property owner". ${ }^{7}$ Alternatively, 3000 Acres works closely with stakeholders to comply with strict land use procedures and to translate these to help community groups access land. Productive gardens are currently undefined in legislation with land access tending to be a 'push-and-pull' process - a de- and re- assembling of sorts - as the (unorganised) proliferation of urban agriculture on public land has forced municipalities to respond. Dundas, founder of 3000 Acres, explains the ramifications: "So it goes into this grey area of being an undefined use. And that often means it requires a planning permit. And once it requires a planning permit it costs a lot of money and takes a long time." 3000 Acres is now advocating for urban agriculture to be incorporated into the Victorian planning scheme. Dundas argues that re-zoning would revalue land waiting-in-transit while providing health benefits. The desire to integrate urban greening into planning are echoed by many others who support healthy built environment goals (see Davison and Kirkpatrick 2014; Thompson and McCue 2016; Wolch et al. 2014). Locating the study of food sharing initiatives within literature on healthy built environments goes beyond topics of obesity and food deserts to include urban greening and collective social practices, revealing connections and co-benefits for physical activity, social capital, inclusion, and mental and environmental health (Renalds et al 2010; Wolch et al 2014). The ability to extend these healthy environments is further endorsed when initiatives are replicable, scaleable and connected.

\section{Replicable, scaleable and connected}

A common catchcry across Melbourne's community food movement is the goal for initiatives to be 'replicable and scaleable's. Rather than grow large to remain as one entity, many groups wish for their activities to stay small and accessible to be adapted by others that can then spread across and beyond the city (see Edwards 2011). This research suggests that another aim for the local food community would be to aspire to 'connection' between food sharing initiatives. A food policy researcher explains that: "On one level that's really good, all the grassroots activity ... There's lots of these projects being funded, right, with small bits of funding from different places but what do we know about what's working and what's not working?" A founder of a food sovereignty network also talked about the consequences of size and potential impact for change, referring to how a local

\footnotetext{
${ }^{6}$ See https://www.ripenear.me/faq\#t5n45.

${ }^{7}$ See https://www.ripenear.me/faq\#t3n21.

${ }^{8}$ See http://doingsomethinggood.com.au/projects/urban-forage-and-feast/.
} 
food group or community garden may attempt to talk to council and government but that "...it's nowhere near as effective as being part of a major grouping. So I think the food movement is realising that, and with groups like the Australian City Farmers and Community Gardens Network and Right to Food and Food Sovereignty Alliance and Sustain, there's a building more cohesive movements coming into view."

Stakeholders commented that scaling needs to occur at a number of levels: from the inner to outer suburbs; from grassroots action to government policy; from municipalities to state and federal government; and for food topics to be incorporated across government sectors, including planning, water, agriculture and health. As explained by the food policy researcher, this sectoral integration is essential: "because it's not just about protecting land, it's about ensuring that land is actively farmed into the future as well." A number of organisations are already working towards policy aims which include Right to Food, the Australian Food Sovereignty Alliance, and Sustain. While local council is a powerful and often supportive force, the need to integrate policy across levels of government with involvement of multi-scalar actors is crucial for many issues including climate change (Torabi et al. 2017).

\section{Reflections on Melbourne as a Food Sharing Ecosystem}

From this analysis, assemblage thinking permits an unravelling of complex food sharing initiatives to reveal their dynamism, territorial reach, diverse modes of sharing, and their impact on social inclusion and affect. Furthermore, they also elicit power through making visible alternative uses of urban space. The application of assemblage thinking proves useful for analysing grassroots movements with its focus on flows and its ability to overcome structural perspectives that can often prejudice institutional approaches and dominant actors. However, assemblage thinking does not reveal a holistic picture of the influences and impacts of food sharing within the city. By framing the city as a 'food sharing ecosystem' (see Edwards forthcoming) - as an assemblage of food sharing assemblages - more potential and tenuous relationships could be recognized and drawn across the city to foster and analyse the impact of food sharing initiatives. For example, weaker ties could be strengthened between actors and components to develop more robust connections amongst food sharing initiatives, multi-scalar governance processes, and policy and planning. So too could influences from broader food sharing communities be recognized such as those revealed in the sketch maps as a variety of productive gardens, an extensive food rescue community, and a range of programs to support people seeking asylum and refugees. Certainly, attending to relational flows allows the interconnections between initiatives to be clarified and synergies and instabilities that they create examined. Existing examples that link across sectors include: Open Table's gifting of 
food-from-waste to people in need; the Food Justice Truck's platform that connected people-withmeans to support people seeking asylum; and 3000 Acres and RipeNear.Me's use of technology that demonstrates urban agricultural productive capacity challenging assumptions of the city as a purely consumptive and pollutive place. Such initiatives are far more than sets of social relations driven by forms of structural power. Instead, they represent "amalgams of materials, performances, structural factors, and cognitions whose particular time-space constitution is contingent on the agency of actors and is thus open to improvisation and accident" (Jones and Murphy 2010: 374).

\section{Conclusion}

To conclude, food sharing initiatives are dynamic assemblages that draw in often under-valued and under-utilised actors, produce and spaces. Common characteristics from the case studies highlight that: they are often small-scale yet distributed and networked across the city, they often activate people in the community who are not fully employed, and that initiatives in Melbourne typically exist outside of the capitalist marketplace. Furthermore, many outcomes are not directly economically motivated but foster social connection, community-building, and environmental goals. In the past, such 'small, slow and shared' (see Edwards 2011) community ventures would often be overlooked or ignored. Ultimately, utilising the concept of assemblage as an analytical tool reveals a topic's complexity to generate new lines of inquiry to better understand flows and outcomes. However, food sharing does not operate in a vacuum and is influenced, directly or indirectly, by the policies and planning procedures of the cities within which they operate. While flying under the radar of many formal processes, the rise of the Sustainable Development 2030 Agenda, and its attendant goals that include zero hunger, good health and well-being, sustainable cities and communities, and responsible consumption and production, has placed cities and food at the centre of governance concerns. It is clear from this research in Melbourne that food sharing initiatives (and the actors and components that they comprise) are part of the food landscape and need to be included in any reformulation of policy and planning in cities within the region. Further research is needed to establish a comparative basis for understanding how food sharing initiatives form, evolve and intersect with other agents and organisations elsewhere. There is also a need for more anticipatory governance to direct attention to new demands on regulations around land and food that are being stimulated by diverse food sharing practices. When conceptualised as an assemblage, the impacts and possibilities of food sharing become more visible. By connecting horizontally with other initiatives to form integrated and more robust support networks and vertically to influence different levels of government to develop appropriate legislation, food sharing has the potential to contribute to a broader food movement towards making Melbourne a more resilient, fair and healthy city. 


\section{References}

Anderson, B. and McFarlane, C. 2011 Assemblage and geography, Area, 43(2): 124-127.

Agyeman, J., McLaren, D. and Schaefer-Borrego, A. 2013 Sharing Cities Briefing Note. Friends of the Earth: London.

Armendáriz, V., Armenia, S. and Atzori, A. 2016 Systemic Analysis of Food Supply and

Distribution Systems in City-Region Systems-An Examination of FAO's Policy Guidelines towards Sustainable Agri-Food Systems, Agriculture, 6: 65.

ASRC 2016 ASRC Annual Report 2016. Asylum Seeker Resource Centre, Footscray.

Baldassarre, G. 2015 Adelaide startup Ripe Near Me connects backyard growers with consumers looking to cut down food miles, Start $U p$ Daily, 7 October. Available at: http://www.startupdaily.net/2015/10/adelaide-startup-ripe-near-me-connects-backyard-growerswith-consumers-looking-to-cut-down-food-miles/.

Barrett, B. 1971 The Inner Suburb. The Evolution of an Industrial Area. Melbourne: Melbourne University Press.

Bennett, J. 2010 Vibrant Matter: A Political Ecology of Things. Durham, N.C.: Duke University Press.

Botsman, R. and Rogers, R. 2010 What's mine is yours: The rise of collaborative consumption. London: Harper Collins.

Burch, D., Dixon, J. and Lawrence, M. 2013 Introduction to the symposium on the changing role of supermarkets in global supply food chains: From seedling to supermarket: Agrifood supply chains in Transition, Agriculture and Human Values, 30(2): 215-224.

Buxton, M., Alvarex, A., Butt, A., Farrell, S. and O’Neill, D. 2008 Planning Sustainable Futures for Melbourne's Peri-urban Region. Summary report. Melbourne: RMIT University.

Cambridge University Press 2017 'Sharing'. Available at: http://dictionary.cambridge.org/.

Carey, R., Larsen, K., Sheridan, J. and Candy, S. 2016 Melbourne's food future: Planning a resilient city foodbowl. Victorian Eco-Innovation Lab, University of Melbourne.

Davies, A., Edwards, F., Marovelli, B., Morrow, O., Rut, M. and Weymes, M. 2017a Creative construction: Crafting, negotiating and performing urban food sharing landscapes. Area, 49(4): 510518.

Davies, A., Gray, M., Donald, B. and Knox-Hayes, J. 2017b Sharing economies: Moving beyond binaries in a digital age, Cambridge Journal of Regions, Economy and Society, 10(2): 209-230.

Davies, A., Edwards, F., Marovelli, B., Morrow, O., Rut, M. and Weymes, M. 2017c Making visible: Interrogating the performance of food sharing across 100 urban areas, Geoforum, 86(Nov):136-149.

Davies, A., Edwards, F., Marovelli, B., Morrow, O., Rut, M. and Weymes, M. 2017d Melbourne 
SHARECITY Profile, Trinity College Dublin, Ireland. Available online at: http://sharecity.ie/wpcontent/uploads/2017/02/Melbourne-final.pdf.

Davison, A. and Kirkpatrick, J. 2014 Re-inventing the Urban Forest: The Rise of Arboriculture in Australia, Urban Policy and Research, 32(2): 145-162.

Deleuze, G. and Guattari, F. 1983 Anti-Oedipus. Minneapolis: University of Minnesota Press.

Deleuze, G. and Guattari, F. 1986 Kafka: toward a minor literature. Minneapolis: University of Minnesota Press.

Deleuze, G. and Guattari, F. 1987 A Thousand Plateaus. Minneapolis: University of Minnesota.

Deleuze, G. and Parnet, C. 1977 Dialogues II. New York: Columbia University Press.

Dovey, K. and Ristic, M. 2017 Mapping urban assemblages: the production of spatial knowledge, Journal of Urbanism: International Research on Placemaking and Urban Sustainability, 10(1): 1528.

Edwards, F. forthcoming Food Sharing Ecosystems: An Urban Political Ecology Analysis of Diverse Food Sharing Practices, Geoforum.

Edwards, F. 2011 Small, Slow and Shared: Emerging Social Innovations in Urban Australian Foodscapes, Australian Humanities Review, Nov: 115-134.

Farías, I. and Bender, T. eds. 2009 Urban Assemblages: How Actor-Network Theory Changes Urban Studies. London: Routledge.

Foodbank Australia 2016 Foodbank Hunger Report 2016. North Ryde, NSW.

Gandy, M. 2005 Cyborg urbanization: complexity and monstrosity in the contemporary city, International Journal of Urban and Regional Research, 29: 26-49.

Gaynor, A. 2006 Harvest of the Suburbs. An Environmental History of Growing Food in Australian Cities. Perth: University of Western Australia.

Goodman, D., DuPuis, E. and Goodman, M. 2012 Alternative food networks. London: Taylor and Francis.

Hayes-Conroy, J. 2013 Veggies and visceralities: A political ecology of food and feeling, Emotion, Space and Society, 6: 81-90.

Huse, O., Hettiarachchi, J., Gearon, E., Nichols, M., Allender, S. and Peeters, A. 2017 Obesity in Australia, Obesity Research and Clinical Practice, October. DOI:

https://doi.org/10.1016/j.orcp.2017.10.002.

Jones, M. 2007 Feast: Why humans share food. Oxford: Oxford University Press.

Jones, A. and Murphy, J. 2010 Theorizing practice in economic geography: Foundations, challenges and possibilities, Progress in Human Geography, 35(3): 366-392.

Kennedy, R., Zapasnik, J., McCann, H. and Bruce, M. 2013 All Those Little Machines:

Assemblage as Transformative Theory, Australian Humanities Review, 55: 45-66. 
Latour, B. 1999 Pandora's Hope: Essays on the Reality of Science Studies. Cambridge: Harvard University Press.

McFarlane, C. 2011 The City as Assemblage: Dwelling and Urban Space, Environment and Planning D: Society and Space, 29(4): 649-671.

Malpas, J. 2012 Putting Space in Place: Philosophical Topography and Relational Geography, Environment and Planning D: Society and Space, 30(2): 226-242.

Müller, M. 2015 Assemblages and Actor-networks: Rethinking Socio-material Power, Politics and Space, Geography Compass, 9(1): 27-41.

Müller, M. and Schurr, C. 2016 Assemblage thinking and actor-network theory: conjunctions, disjunctions, cross-fertilisations, Transactions, 41(3), July: 217-229.

Prince, R. 2017 Local or global policy? Thinking about policy mobility with assemblage and topology, Area, 49(3): 335-341.

Pryor, T. 2008 Food For All: How local government is improving access to nutritious food.

Melbourne: VicHealth. July.

Renalds, A., Smith, T. and Hale, P. 2010 A systematic review of built environment and health,

Family Community Health, 33(1): 68-78.

Sassen, S. 2007 Territory, Authority, Rights: From Medieval to Global Assemblages. Princeton:

Princeton University Press.

Schor, J. 2010 Plenitude: The new economics of true wealth. Victoria: Scribe.

Sheridan, J., Carey, R. and Candy, S. 2016 Melbourne's Foodprint: What does it take to feed a city? Victorian Eco-Innovation Lab, University of Melbourne.

Swyngedouw, E. 2006 Circulations and metabolisms: (hybrid) natures and (cyborg) cities, Science as Culture, 15: 105-121.

Thompson, S. and McCue, P. 2016 Healthy Planning: An evolving collaborative partnership, Urban Policy and Research, 34(1): 1.

Torabi, E., Dedekorkut-Howes, A. and Howes, M. 2017 Not waving, drowning: Can local government policies on climate change adaptation and disaster resilience make a difference? Urban Policy and Research, 35(3): 312-332.

Wolch, J., Byrne, J. and Newell, J. 2014 Urban green space, public health and environmental justice: The challenge of making cities 'just green enough', Landscape and Urban Planning, 125: 234-244.

\section{Acknowledgments}

This project received funding from the European Research Council under the European Union's Horizon 2020 research and innovation programme [Grant Agreement No. 646883]. 